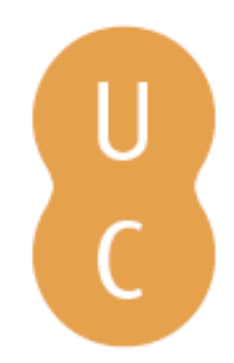

\title{
nommalina
}

\section{Influence of relief on the vegetation fires occurrences in the urban area of Juiz de Fora, MG, Brazil}
Autor(es):
Torres, Fillipe Tamiozzo Pereira; Ribeiro, Guido Assunção; Martins, Sebastião Venâncio; Lima, Gumercindo Souza

Publicado por: Imprensa da Universidade de Coimbra

URL persistente:

URI:http://hdl.handle.net/10316.2/34321

DOI:

DOI:http://dx.doi.org/10.14195/978-989-26-0884-6_91

Accessed : $\quad$ 26-Apr-2023 14:24:51

A navegação consulta e descarregamento dos títulos inseridos nas Bibliotecas Digitais UC Digitalis, UC Pombalina e UC Impactum, pressupõem a aceitação plena e sem reservas dos Termos e Condições de Uso destas Bibliotecas Digitais, disponíveis em https://digitalis.uc.pt/pt-pt/termos.

Conforme exposto nos referidos Termos e Condições de Uso, o descarregamento de títulos de acesso restrito requer uma licença válida de autorização devendo o utilizador aceder ao(s) documento(s) a partir de um endereço de IP da instituição detentora da supramencionada licença.

Ao utilizador é apenas permitido o descarregamento para uso pessoal, pelo que o emprego do(s) título(s) descarregado(s) para outro fim, designadamente comercial, carece de autorização do respetivo autor ou editor da obra.

Na medida em que todas as obras da UC Digitalis se encontram protegidas pelo Código do Direito de Autor e Direitos Conexos e demais legislação aplicável, toda a cópia, parcial ou total, deste documento, nos casos em que é legalmente admitida, deverá conter ou fazer-se acompanhar por este aviso.

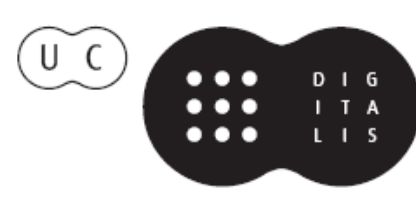




\section{ADVANCES IN}

Forest Fire

\section{RESEARCH}

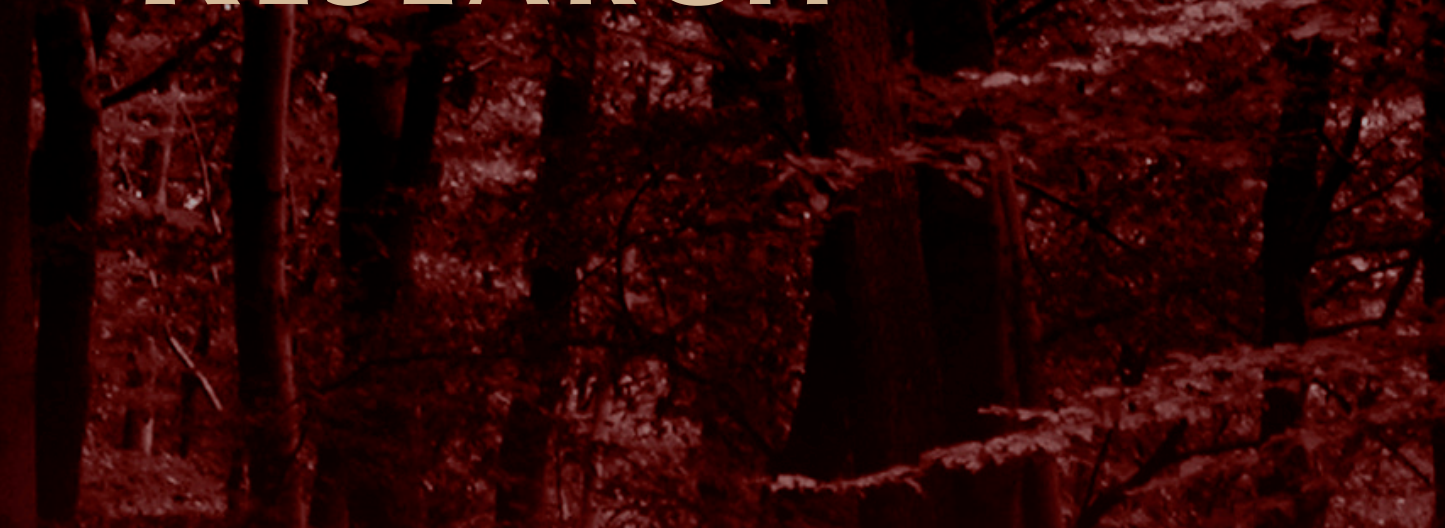

\section{DOMINGOS XAVIER VIEGAS}

\section{EDITOR}




\title{
Influence of relief on the vegetation fires occurrences in the urban area of Juiz de Fora, MG, Brazil
}

\author{
Fillipe Tamiozzo Pereira Torres, Guido Assunção Ribeiro, Sebastião Venâncio Martins, Gumercindo \\ Souza Lima
}

Universidade Federal de Viçosa, DEF, campus universitário 36570-000, torresftp@yahoo.com.br, gribeiro@ufv.br,venancio@ufv.br, gslima@ufv.br

\begin{abstract}
Wildfires cause irreversible damage to the environment, whether in the flora, fauna, people and large economic losses. Knowing the profile of forest fires, traced through different variables, it is essential to have guidelines to establish polices for protection planning. The statistics of occurrences are the main tools to know the profile of fires to planning the prevention and to control more efficiently, reducing costs, time and fight risk. This study used the coordinates of each of the 3,754 occurrences in the city of Juiz de Fora, MG, Brazil, for the period $01 / 01 / 2002$ to $12 / 31 / 2011$. The land aspect, the shape and the slope land of each event was determined in order to analyze the influence of the relief on the number of fire occurrence. According to the results, the relief influences directly the occurrence and fire spread. The northern aspect with greater slope and forms that facilitate the flow of water had a higher number of cases. The influence of relief is also confirmed by the relationship between wind direction and occurrences. Land exposures that directly receive the daily prevailing winds have a higher probability of occurrence of fire.
\end{abstract}

Keywords: Relief, Fire, Susceptibility

\section{Introduction}

The fires in vegetation are directly responsible, not only for environmental damage, but also economic and social losses whose dimensions often reach invaluable levels (Vosgerau et al., 2006).

There are two types of factors that determine the degree of fire danger: the constant factors, represented by the fuel type, which involves different types of vegetation and topography; and variable factors, represented by atmospheric conditions (Torres et al., 2011). Besides the listed factors it includes the land use and occupation.

The topography, according to Batista (2000), influences the climate and determines the type of fuel. Considering that fire behaviour is largely the result of the climate and fuel available, it can be said that the topography indirectly influence on the behaviour of the fire and the flames directly by the greater proximity the higher slope. So, we conclude that the relief is fundamental in establishing prevention and control plans.

To preserve the environment from the harmful effects of fires, it is essential that protectionist policies be appropriate to the characteristics of each region. It is necessary to know when and why the events occur. The statistics of occurrence are the main tools to trace its profile. With these data, the control can be planned more efficiently. The lack of this information can underestimate or overestimate the expenses relating to the protection of the environment, endangering the survival of forests and fighters (Santos, Soares and Batista, 2006). According to Vosgerau et al. (2006) in Brazil, there is a lack of effective plans for prevention and control. These plans can only be organized and put into practice by evaluating information to report precisely the characteristics of the occurrences of fires

To prioritize areas of greatest risk with intensive programs of protection and structure services of fire fight, in economically feasible limits, it is important to know the locations and the cause of occurrences and the factors of spread. Knowing the factors that contribute to the higher incidence of fire, it may 
concentrate efforts and resources to fight it, because these systems are relatively expensive and would be impossible to keep them continuously in all locations.

The aim of this study was to analyse the influence of relief, such as the Sun aspect, The shape of the slopes, the inclination and its position in relation to the prevailing winds, on the occurrence of vegetation fires in the city of Juiz de Fora, Minas Gerais State, Brazil in order to trace the events, giving to the government tools to improve the prevention and fight policies.

\section{Methods}

The municipality of Juiz de Fora, with a population of 516,247 inhabitants (IBGE, 2010) and coordinates $21^{\circ} 41^{\prime} 20^{\prime \prime} \mathrm{S}$ and $43^{\circ} 20^{\prime} 40^{\prime \prime} \mathrm{W}$, is located in the southeastern state of Minas Gerais, (Figure $1)$,

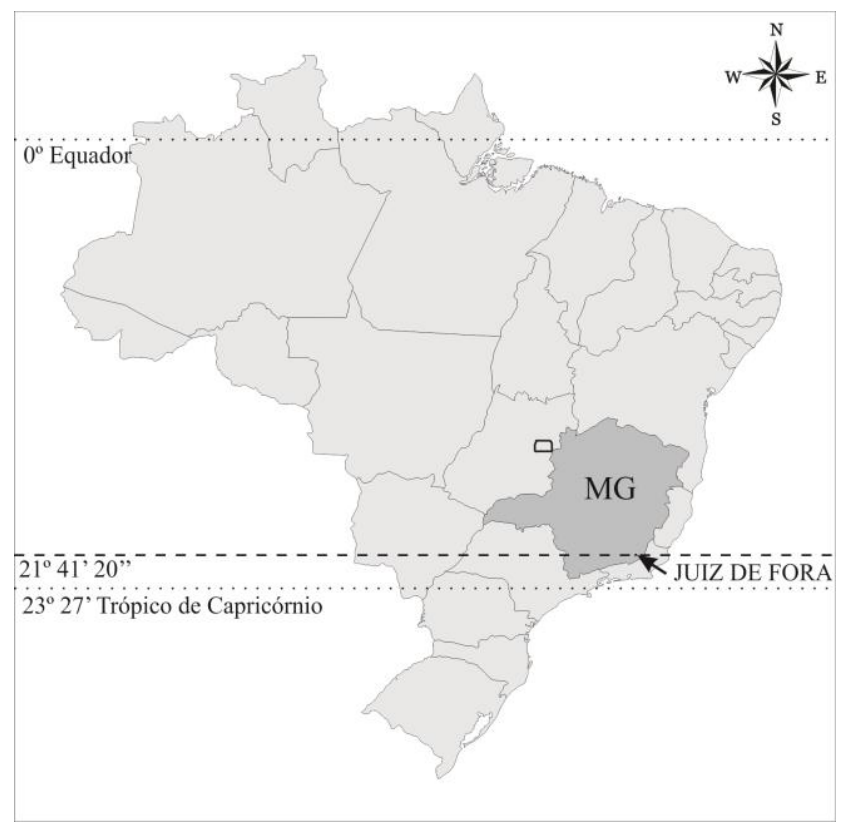

Figure 1. Location of the study area

The area is extremely mountainous, reaching 1,000 meters of altitude at the highest point and 670-750 $\mathrm{m}$ in the valley bottom. The urban area falls entirely on the middle reaches of the Paraibuna River belonging to the Paraíba do Sul river basin (PJF, 1996).

The relief patterns show a strong tendency to a structural orientation. Their lithologies are characterized by having coverages of thick soils and rock exposures, mainly in the areas of occurrence of charnockitic rocks, to south of the city. In general geomorphological features tend to a convexity of slopes from the top, together with the formation of large number of amphitheatres and plains. The central core of the city, taking advantage of this natural condition, lodged in the enlarged section of the Paraibuna river valley, strangled by a sturdy bar, downstream (PJF, 1996).

The data of fires occurrences in vegetation were obtained in the 4th Battalion of Military Firefighters (4th BBM). We use 3,754 fire occurrences taking the nature, date, time and address for the period 01/01/2002 to 31/12/2011, within the urban area.

All places of occurrences were geocoded and tabulated. The exposures were grouped into strands North $\left(315^{\circ}\right.$ to $\left.45^{\circ}\right)$, East $\left(45^{\circ}\right.$ to $\left.135^{\circ}\right)$, South $\left(135^{\circ}\right.$ to $\left.225^{\circ}\right)$ and West $\left(225^{\circ}\right.$ to $\left.315^{\circ}\right)$, by using a compass. The shapes were got by visual interpretation, classified in concave and convex rectilinear. The slopes classes was determined with the Abney clinometer and grouped into classes from $0^{\circ}$ to $10^{\circ}$, $10^{\circ}$ to $20^{\circ}, 20^{\circ}$ to $30^{\circ}, 30^{\circ}$ to $40^{\circ}$ and $>40^{\circ}$. 
The preferred directions of the winds were recorded in Principal Climatological Station, located at the Federal University of Juiz de Fora (UFJF). Data were collected at 9:00, 15:00 and 21:00 UTC. From the readings of the three times, the preferred direction for each day of the series divided into North, Northeast, Northwest, West, East, South, Southeast and Southwest was determined.

\section{Results and Discussion}

Figure 2 shows that there was a significant influence of exposure of the slopes on events where most of the fires occurred in North aspect $(\mathrm{N})$ followed by the West aspect (W), East aspect (E) and the lowest on the South aspect (S).

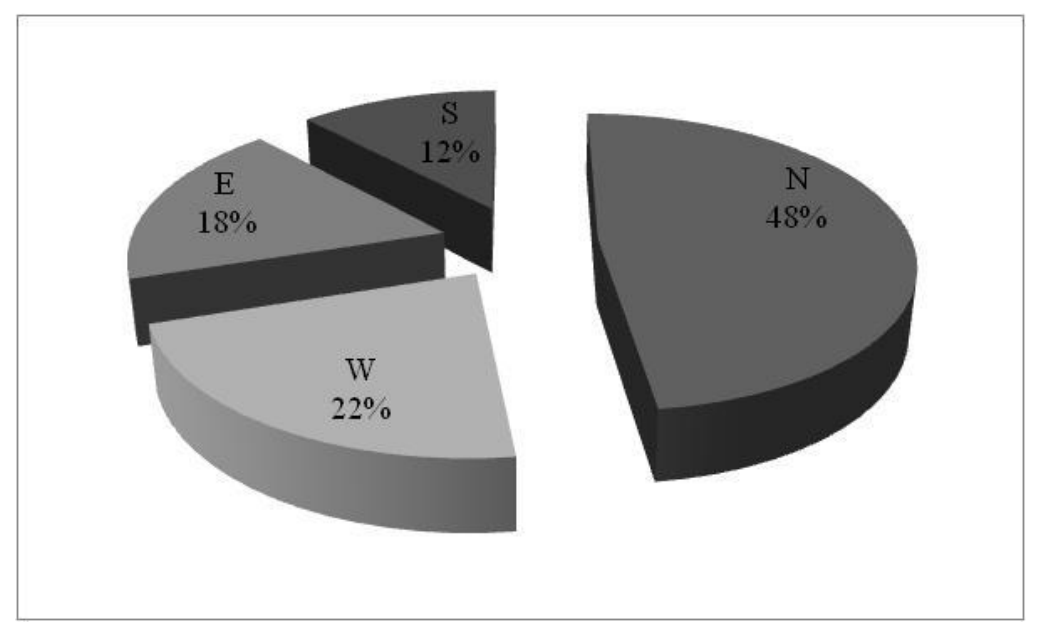

Figure 2. Occurrences of fires in agreement with the exhibition of the slope

This distribution is due to the fact that surfaces with different orientations and inclinations receive different amounts of solar radiation compared to a flat surface, in the same location and time of year (Torres \& Machado, 2011). The Sun culminates at zenith (representing greater energy gain) in places whose latitude is equal to the tilt of Earth's axis. Thus, the equinoxes (March 21 and September 23) the Sun culminates at zenith over the equator, with these dates, in all places on Earth, days and nights of equal length. At the Summer Solstice in the South and Winter Solstice in the Northern Hemisphere (December 22), the Sun culminates at zenith for latitude $23^{\circ} 27^{\prime}$ (South), because this is the greatest declination reached the southern hemisphere, this latitude is called the Tropic of Capricorn. On June 21 the Sun culminates at the zenith to $23^{\circ} 27^{\prime}$ (North) latitude that defines the position of the Tropic of Cancer, has thus the Summer Solstice in the Northern Hemisphere and Winter Solstice in the Southern Hemisphere for the higher latitudes $23^{\circ} 27^{\prime}$ the sun does not culminate on zenith on any day of the year.

We observe, therefore, that the sun for much of the year culminates in Zenith north of the city of Juiz de Fora, located at latitude $21^{\circ} 41^{\prime} 20^{\prime \prime} \mathrm{S}$. This factor tends to raise the temperature in the areas of North orientation directly influencing the physical characteristics of fuel and fire occurrences.

The difference between the West and te East aspect can be explained by the hour of greatest concentration of occurrences (between 15 and 16 hours), during this time the slope the West aspect is getting greater amount of solar energy relative than East aspect, increasing the percentage of occurrences. Another factor is the West aspect receives more energy in the afternoon when the earth's surface and the air are already heated and usually there is no fog. Beside these, the East aspect get humid winds from the Atlantic Ocean, distant, straight, about $150 \mathrm{~km}$ from the city.

Hugget (1995) points out that in the southern hemisphere, oriented north slopes receive more insolation than facing the South, which, in turn, receive higher rainfall due to moisture-laden winds from the sea (SW, S and SE). Oliveira et al. (1995) found significant differences in the two approaches 
with respect to parameters such as temperature, precipitation and humidity. According to these authors, the South aspect has leaf litter on average $41.9 \%$ more humid than those toward the North. The authors also claim that the loss of this moisture also occurs much faster on North aspect, because the South one retains moisture 1.6 times more. Consequently soil moisture behaves the same way, only varying according to the type of associated vegetation.

This moisture variation is reflected primarily due to different rates of temperature of these two types of aspects, since the North are significantly warmer due to higher incidence of heat that turned to the South, with $98 \%$ occurrence of maximum temperatures on those aspects. The minimum temperature also occurred mostly in the northern aspect (86\%), which should be attributed to higher relative humidity in the South, over the longer period of deposition of dew that acts as a "buffer" effect reducing extreme temperatures (Oliveira et al., 1995).

At low relative humidity, the probability of occurrence and spread of fire is greater in view of the direct correlation with the drying of the fuel. The thinnest material, represented by one of time lag of an hour, according the Brown (1982) classification is present in greater quantities and in most environments. In critical weather situations, this material comes to lose up to $66 \%$ humidity in the range of an hour, leading the fuel moisture below the extinction moisture.

According to Nunes (2005) this is due to atmospheric humidity have a direct effect on the flammability of fuels, with a constant moisture exchange between the atmosphere and plant dead. The dry material in a humid atmosphere absorbs water and releases water when the air is dry. The amount of moisture that dead material can absorb or release depends on the relative humidity. During extremely dry periods, moisture may even affect the moisture content of dead or live material.

Furthermore, there are internal variations within geomorphological character that individualize the slopes more or less favorable to the fire occurrence. These are geometric segments which are presented in three main forms: concave, convex and straight. The concave shapes are characterized as areas of convergence of flow and consequently a higher concentration of moisture, while the convex and straight (on slopes) influence the formation of zones of divergence of water and low moisture content and thus more susceptible to the fire occurrence (Coura, Souza \& Fernandes, 2009).

This influence is confirmed by the results of the study (Figure 3), showing the largest number of occurrences and the convex rectilinear strands in relation to concave.

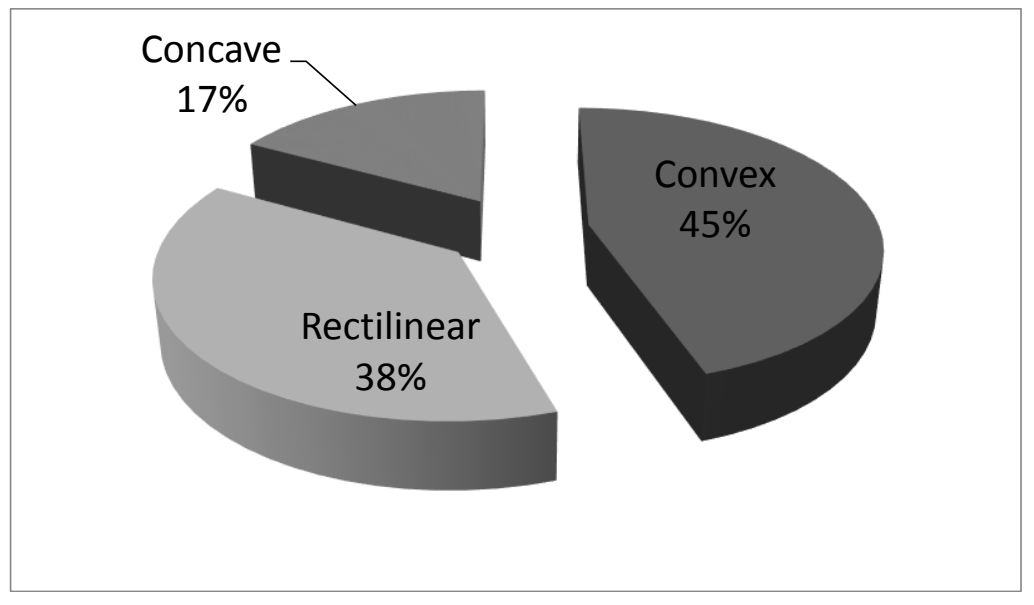

Figure 3. Fire according to the shape of the slope

Regarding the slope, the data point to the following results (Figure 4), confirming that greater when the slope the greater the percentage of occurrences. 


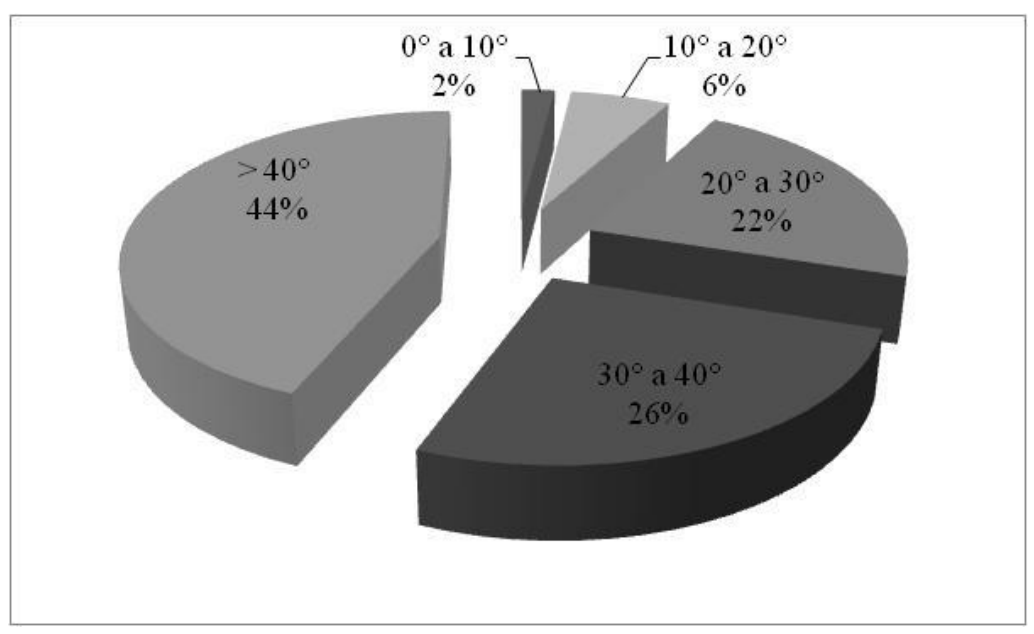

Figure 4. Fires according to the slope

The influence of slope can be explained due to the humidity, according Valeriano (2008), on steeper slopes, it can realize easily that rainwater flows very quickly, seeping in smaller quantities, making it the driest place.

Besides the interference of inclination in water flow, Viegas (2004) explains that the spread of fire in places with some slope is distinct from behavior that occurs in areas without slope, due the effect of additional factors such as convection and radiation. If there are minimum declivity, the rate of spread tends to grow and will be greater the larger the microclimatic changes in the combustion zone. This fact is also confirmed by Ribeiro et al. (2008) when they argue that the intensity of the fire in the areas of acclivity is greater due to overheating of fuel above the front of the fire line, the flames closer when compared to flat terrain. On the other hand, the wind tends to help as much on the drying of the fuel material as the spread of fire.

The wind is a major factor in the combustion rate and spread of the fire like described by Torres et al. (2011) in addition to affecting the rate of oxygen supply during the burning. The drying of the fuel is accelerated by the removal of the air layer in contact with the surface and induce the tilt of the flames, approaching those of the material not yet burnt and hastening the preheating stage.

The data (Table 1) show the relation between the wind direction and the occurrences of fires. Slopes to windward of the preferred daily winds have higher numbers of occurrences of fires. When the preferred wind direction is north, there is a predominance of fires in windswept strand with the same direction $71 \%$ of the occurrences. When the wind direction is north-west, $87 \%$ of the occurrences are located on slopes facing $\mathrm{N}$ and $\mathrm{W}$; when the direction is north-east there is a greater number of occurrences in the areas $\mathrm{N}$ and $\mathrm{E}$ with $81 \%$ of fires in these respects; with the wind direction West, $77 \%$ of cases occur in the present toward the $\mathrm{W}$; the preferred direction of the wind when it favours eastern occurrences hillsides $\mathrm{N}$ and $\mathrm{E}$. This influence can be best observed when the winds are predominant directed in the southern quarter (SW, S , SE), where there is a superiority of occurrences in the southern side, countering the dominance of events that occurs in slopes with further guidance. When the situation is calm (C) without occurrence of winds, the situation normalizes in relation to the order observed in Figure 2 with higher occurrences in the present N, then the slopes neatly Exposure $\mathrm{W}, \mathrm{E}$ and $\mathrm{S}$. 
Table 1. Percentage of occurrences according to the location of the fire and the wind direction

\begin{tabular}{cccccccccc} 
Slope & & \multicolumn{8}{c}{ Wind direction } \\
occurrence & $\mathbf{N}$ & $\mathbf{N W}$ & $\mathbf{N E}$ & $\mathbf{W}$ & $\mathbf{E}$ & $\mathbf{S W}$ & $\mathbf{S E}$ & $\mathbf{S}$ & $\mathbf{C}$ \\
North (N) & $71 \%$ & $44 \%$ & $54 \%$ & $23 \%$ & $40 \%$ & $22 \%$ & $28 \%$ & $33 \%$ & $65 \%$ \\
West (W) & $15 \%$ & $43 \%$ & $15 \%$ & $77 \%$ & $25 \%$ & $41 \%$ & $12 \%$ & $23 \%$ & $26 \%$ \\
$\begin{array}{c}\text { East (E) } \\
\text { South (S) }\end{array}$ & $10 \%$ & $8 \%$ & $27 \%$ & $0 \%$ & $29 \%$ & $9 \%$ & $29 \%$ & $8 \%$ & $6 \%$ \\
$\begin{array}{c}\text { \% of days with } \\
\text { prevailing wind }\end{array}$ & $20 \%$ & $5 \%$ & $4 \%$ & $0 \%$ & $6 \%$ & $28 \%$ & $31 \%$ & $36 \%$ & $3 \%$ \\
\end{tabular}

In summary, when the wind direction is the same as the orientation of the slope, there is the named "wind up the hill" in this situation the wind accelerates the spread of fire, whereas it tends to raise the flames of bottoms for higher still unburned.

\section{Conclusion}

The results of this study allow us to conclude that:

- the land aspect has a direct correlation on the fires occurrences;

- the North aspect have a higher percentage of occurrences for receiving greater amount of solar energy during the year;

- the west aspect were in second place with more fire occurrences, which can be explained by the time in which they receive higher solar radiation that coincides with the time of lower humidity;

- the slopes to windward of the preferred daily winds are more susceptible to the occurrence;

- those aspects that favour the spread of water tend to have higher number of occurrences;

- the higher the slope the greater the number of events;

- the strategies to prevent fires must take into account the influences of topography and the prevailing winds through preventative in areas more conducive to the event work. Also the fight actions must take into account such information, reducing the costs and risks of operations.

\section{References}

Batista, A. C. (2000). Mapas de risco: uma alternativa para o planejamento de controle de incêndios florestais. Floresta, Curitiba, v.30, n.1/2, p.45-54.

Brown, J. K. et al. (1982). Handbook for inventorying surface fuel and biomass in the Interior West. Ogden: Intermountain Forest and Range Experiment Station.

Coura, P. H. F.; Sousa, G. M. E Fernandes, M. C. (2009). Mapeamento geoecológico da susceptibilidade à ocorrência de incêndios no Maciço da Pedra Branca, município do Rio de Janeiro. Anuário do Instituto de Geociências - UFRJ, Rio de Janeiro, v.32, n.2, p.14-25.

Hugget, R. J. (1995). Geoecology: an evaluation approach. Londres: Editora London.

IBGE. (2010). Censo Demográfico 2010. Rio de Janeiro: Instituto Brasileiro de Geografia e Estatística.

Nunes, J. R. S. (2005) FMA+ - Um novo índice de perigo de incêndios florestais para o Estado do Paraná - Brasil. Tese (Doutorado em Engenharia Florestal) - Setor de Ciências Agrárias, Universidade Federal do Paraná, Curitiba.

Oliveira, R. R. et al. (1995). Significado ecológico da orientação de encostas no Maciço da Tijuca. Oecologia Brasiliensis, Rio de Janeiro, v. 1, p.523-541.

PJF. (1996). Plano Diretor de Juiz de Fora. Juiz de Fora: Concorde, 1996. 
Ribeiro, L. et al. (2008). Zoneamento de riscos de incêndios florestais para a fazenda experimental do Canguiri, Pinhais (PR). Floresta, Curitiba, v.38, n.3, p.561-572.

Santos, J. F.; Soares, R. V. E Batista, A.C. (2006). Evolução do perfil dos incêndios florestais em áreas protegidas no Brasil, de 1993 a 2002. Floresta, Curitiba, v.36, nº1, p.93-100.

Torres, F. T. P. et al. (2001). Correlações entre os elementos meteorológicos e as ocorrências de incêndios florestais na área urbana de Juiz de Fora, MG. Revista Árvore, Viçosa, v.35, n.1, p.143150, 2011.

Torres, F. T. P. E Machado, P. J. de O. (2011). Introdução à Climatologia. São Paulo: Cengage Learning.

Valeriano, M. M. (2008). Dados topográficos. In: FLORENZANO, T. G Geomorfologia: conceitos e tecnologias atuais. São Paulo: Oficina de textos.

Viegas, D. X. (2004). Cercados pelo fogo. Coimbra: Editorial Minerva.

Vosgerau, J. L. et al. (2006). Avaliação dos registros de incêndios florestais no Estado do Paraná no período de 1991 a 2001. Floresta, Curitiba, v.36, n.1, p.23-32. 